\title{
Extract from Serenoa repens Suppresses the Invasion Activity of Human Urological Cancer Cells by Inhibiting Urokinase-Type Plasminogen Activator
}

\author{
Kenichiro IshiI, ${ }^{a}$ Shigeyuki Usui, ${ }^{a}$ Yoshiki Sugimura, ${ }^{b}$ Hajime Yamamoto, ${ }^{c}$ Kazuhiro Yoshikawa, ${ }^{d}$ \\ and Kazuyuki HiRAno*,a \\ Laboratory of Pharmaceutics, Gifu Pharmaceutical University, ${ }^{a}$ 5-6-1 Mitahora-higashi, Gifu 502-8585, Japan, \\ Department of Urology, Aichi Cancer Center Research Institute, ${ }^{b}$ 1-1 Kanokoden, Chikusa-ku, Nagoya 464-8681, Japan, \\ Toyama Prefectural Central Hospital, ${ }^{c}$ 2-2-78 Nishinagae, Toyama 930-8550, Japan, and Second Department of \\ Pathology, Aichi Medical University, 21 Karimata, Yazako, Nagakute-cho, Aichi-gun, Aichi 480-1195, Japan. \\ Received August 15, 2000; accepted October 24, 2000
}

\begin{abstract}
We used three human urological cancer cell lines, PC-3, LNCaP and SKRC-1, to investigate the effects of the extract from Serenoa repens (Palmae) on tumor cell invasion. The invasion activity of these cell lines was determined in vitro using a Transwell cell-culture chamber. The invasion activity of PC-3 cells into Matrigel was effectively suppressed by the extract at the concentration range of $1-10 \mu \mathrm{g} / \mathrm{ml}$, while that of LNCaP and SKRC-1 cells was unaffected by the extract. The extract did not affect the viability, adhesion ability, or motility of the cell lines. UPA is more strongly expressed on the membrane fraction of PC-3 cells than that of LNCaP or SKRC-1 cells. The purified uPA activity is inhibited by the extract from $S$. repens in a dose-dependent manner, suggesting that the suppression of PC-3 cell invasion by the extract is based on an inhibition of the uPA activity which is necessary for tumor cell invasion. These data suggest that the extract from $S$. repens specifically inhibits the uPA activity and may therefore be useful for the therapeutic treatment of prostate cancer.
\end{abstract}

Key words Serenoa repens; urokinase-type plasminogen activator; tumor cell invasion

The pharmacological use of plants and herbs (phytotherapy) for the treatment of benign prostatic hyperplasia (BPH) has been growing steadily. Serenoa repens (Palmae) is a small palm tree native to the Atlantic coast of North America. A lipidosterolic extract from $S$. repens is therapeutically has been used to treat BPH patients for many years. ${ }^{1,2)}$ The effect of extract from $S$. repens on BPH tissue was investigated and explained through the inhibition of $5 \alpha$-reductase and/or the binding of androgens to their receptors. ${ }^{3,4)}$

Prostate cancer is the most frequently diagnosed cancer among men in the U.S. Metastasis of a primary tumor to vital organs is the dominant cause of cancer related deaths. ${ }^{5}$ ) Tumor invasion is a complex process involving cell adhesion, motility (migration) and the degradation of tissue barriers by proteases secreted by tumor cells. Cancer cells possess a high degree of proteolytic activity, resulting in acquisition of the ability to degrade and consequently invade surrounding normal tissues. ${ }^{6}$ Several proteases such as urokinase-type plasminogen activator (UPA), matrix metalloproteases (MMPs) and aminopeptidase N (AP-N) are necessary for tumor cell invasion into the basement membranes.

In the present study, we investigate the effects of the extract from $S$. repens to human urological cancer cell invasion, and then clarify the suppressive mechanisms of tumor cell invasion by the extract.

\section{MATERIALS AND METHODS}

Materials The extract from S. repens (Palmae) was obtained by extracting the fruits with carbon dioxide under hypercritical conditions according to the method previously reported. ${ }^{7)}$ UP-001 (a potent inhibitor of uPA), purified MMP-2 from normal human fibroblast and recombinant MMP-9 were the generous gift of Ono Pharmaceutical Co., Ltd. (Osaka).
Purified uPA from human urine was generously provided by JCR Pharmaceuticals Co., Ltd. (Ashiya). Purified AP-N from human prostate was used for experiments. Fluorogenic substrates for enzymes were purchased from Peptide Institute (Osaka). All other chemicals were of analytical grade.

Cell Culture PC-3 and $\mathrm{LNCaP}$ cells derived from human adenocarcinoma of the prostate, and SKRC-1 cells from human renal carcinoma were routinely cultured in DMEM containing $10 \%$ fetal calf serum under a humidified atmosphere of $5 \% \mathrm{CO}_{2}$ in air.

Invasion Assay The invasion activity of tumor cells using Transwell cell-culture chambers was assayed according to the methods reported by Albini et al. ${ }^{8)}$ with some modifications. Briefly, the upper surface of the cell culture inserts with an $8.0 \mu \mathrm{m}$ pore size (FALCON Labware) was precoated with $5 \mu \mathrm{g} /$ filter of Matrigel in phosphate-buffered saline (PBS) and dried at room temperature under a hood. Cell suspensions $\left(3 \times 10^{4}\right.$ cells/filter $)$ with or without the extract were added to the upper compartment, and incubated for a certain period (PC-3; $24 \mathrm{~h}, \mathrm{LNCaP} ; 48 \mathrm{~h}$, SKRC-1; $12 \mathrm{~h}$ ) at $37^{\circ} \mathrm{C}$ in a $5 \% \mathrm{CO}_{2}$ atmosphere. After incubation, the filters were fixed with $5 \%$ glutaraldehyde and stained with Giemsa's solution. The cells on the upper surfaces of the filter were wiped off with cotton swabs. The cells which appeared on the lower surface were manually counted under a microscope at a magnification of $200 \times$. Each assay was performed in triplicate.

Cell Viability and Adhesion to the Matrigel Cell viability and adhesion to Matrigel were assayed according to the methods reported by Iguchi et al. ${ }^{9)}$

Wound Assay The wound assay was performed according to the methods reported by Goodman et al. ${ }^{10)}$ with some modifications. After wounding, PC-3 cells were treated with the extract from $S$. repens (final concentration; $10 \mu \mathrm{g} / \mathrm{ml}$ ) for 
$24 \mathrm{~h}$, and the effects of the extract on the cell motility were evaluated by comparing to control results.

Assay of Enzyme Activity uPA and AP-N activities were determined fluorometrically with excitation at $380 \mathrm{~nm}$ and emission at $460 \mathrm{~nm}$ using 4-aminocoumarin (AMC) derivatives as substrates. MMP-2 and MMP-9 activities were determined fluorometrically with excitation at $328 \mathrm{~nm}$ and emission at $393 \mathrm{~nm}$ using (7-methoxycoumarin-4-yl) acetyl (MOCAc) derivatives as substrates.

Statistical Analysis The significance of differences between groups was calculated by applying the Student's $t$-test.

\section{RESULTS AND DISCUSSION}

The effects of the extract from $S$. repens on human urological cancer cell invasion were investigated in vitro using a Transwell cell-culture chamber coated with Matrigel. As shown in Fig. 1, the invasion activity of PC-3 cells was effectively suppressed by the extract in a dose-dependent manner, while that of LNCaP and SKRC-1 cells was unaffected by the extract. The extract has no effect on the viability, adhesion ability, or motility of human urological cancer cells, indicating that the degradation of Matrigel in PC-3 cell invasion may be affected by the extract.

Inhibition of the enzymes, uPA, MMP-2, MMP-9 and AP$\mathrm{N}$ related to tumor cell invasion by the extract was determined using synthetic substrates as shown in Table 1. uPA was selectively inhibited by the extract but no effect of the extract on the activities of MMPs and AP-N was observed. Kinetic analysis of the UPA inhibition by the extract showed apparently noncompetitive inhibition with a $K_{\mathrm{i}}$ value calculated to be $1.8 \mu \mathrm{g} / \mathrm{ml}$. Although the expression of uPA in the cell lines was determined and high activity of uPA cells was detected in the membrane fraction of PC-3 cells, the level of uPA expressed in LNCaP and SKRC-1 cells was found to be low. The specific activity for uPA in the membrane fraction of PC-3 cells was determined to be $40 \mathrm{pmol} / \mathrm{min} / \mathrm{mg}$ protein and this activity was about 4 times higher than that of LNCaP and SKRC-1 cells. To confirm the mechanism for suppression of the cell invasion by the extract, UP-001, a specific inhibitor for uPA but not for tPA, was used as a positive control. The invasion activity of PC-3 cells was effectively suppressed by UP-001 in the concentration range of $0.1-10 \mu \mathrm{M}$, and the half inhibition concentration was shown to be $1 \mu \mathrm{M}$. The invasion activity of LNCaP and SKRC-1 cells was unaffected by UP-001 at the same concentration. The uPA activity was also inhibited by UP-001 $\left(K_{\mathrm{i}}=0.3 \mu \mathrm{M}\right)$ at a concentration similar to that suppressing the invasion activity. These data demonstrate that the suppression of PC-3 cell invasion by the extract is based on the specific inhibition of the UPA activity by the extract.

Van Veldhuizen et al. ${ }^{11)}$ reported that high levels of uPA expression were seen in $71 \%$ of prostate cancer patients by immunohistochemistry, suggesting that it may play a key role in promoting prostate cancer growth and metastasis. Moreover, Miyake et al. ${ }^{12)}$ showed that the elevation of uPA and uPAR concentrations in human serum could be used as a predictor of progression and prognosis in patients with prostate cancer. In contrast, Stephan et al. ${ }^{13)}$ indicated that RCC tumor cells modestly overexpressed uPA-receptor mRNA, while uPA mRNA expression was significantly decreased.

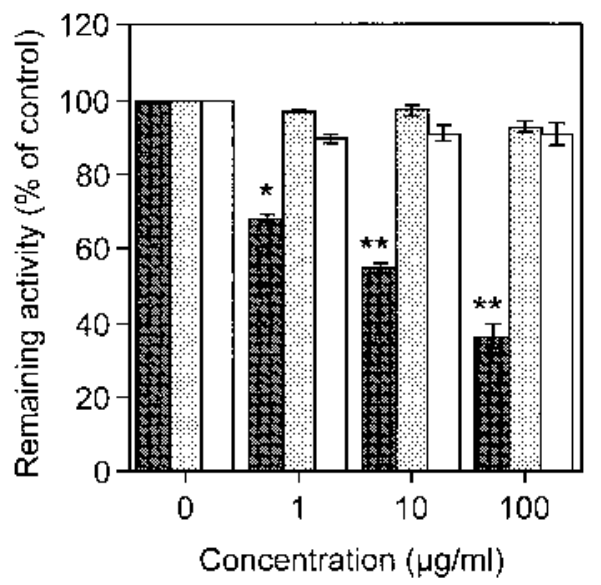

Fig. 1. Effects of the Extract from S. repens on the Invasion Activity of Human Urologic Cancer Cell Lines

PC-3 (ם), LNCaP (⿴囗十) and SKRC-1 $(\square)$ cells $\left(3 \times 10^{4}\right.$ cells/well) were seeded with the extract into the upper compartment of a Transwell chamber pre-coated with Matrigel and the chamber was incubated for a given period in a $\mathrm{CO}_{2}$ incubator. After incubation, the cells invading the lower surface of the membrane of the chamber were counted. Data presented are the mean \pm S.D. values of three different experiments. $* p<0.01, * * p<0.001$ versus control.

Table 1. Effects of Extract from $S$. repens on the Activity of Enzymes Related to Tumor Cell Invasion

\begin{tabular}{lc}
\hline \hline Enzyme & $\mathrm{IC}_{50}(\mu \mathrm{g} / \mathrm{ml})$ \\
\hline uPA & 2 \\
MMP-2 & $>100$ \\
MMP-9 & $>100$ \\
AP-N & $>100$ \\
\hline
\end{tabular}

However, Los et al. ${ }^{14)}$ recently reported that the expression of UPA and UPAR was lower in tumor tissues compared with that in the adjacent normal tissues in kidney. Our data also suggest that uPA may play a role in invasion by prostate cancer but not by renal cancer-derived cell lines.

The extract from $S$. repens is composed of $85 \%$ fatty acids, mainly lauric, myristic, palmitic, oleic, and stearic acids. The beneficial effects of these extracts on the treatment of BPH have been explained by their anti-inflammatory potential, ${ }^{7,15)}$ and by an inhibitory effect for $5 \alpha$-reductase. ${ }^{16)} \mathrm{du}$ Toit et al. also reported that the essential fatty acids inhibited the UPA activity and expression. ${ }^{17,18)}$ Oleic acid and long chain fatty acids were found to exhibit an inhibition in binding of single chain urokinase (scuPA) to the urokinase receptor. ${ }^{19)}$ Taking the above results and discussions into consideration, fatty acid components in the extract are likely to inhibit the uPA activity.

In conclusion, the inhibition of UPA activity by the extract from $S$. repens in human prostate cancer cells such as PC-3 is responsible for the suppression of cell invasion. Therefore, the extract from $S$. repens may be applicable in the therapeutic treatment of metastasis of prostate cancer as well as prostatitis and $\mathrm{BPH}$.

Acknowledgments We are grateful to Dr. Simon W. Hayward in the Department of Urology, University of California, San Francisco for critical suggestions on the manuscript. This study was supported in part by the following grants: Ministry of Education, Science, Sports and Culture of 
Japan (10671508), Bristol-Myers Squibb Unrestricted Biomedical Research Grants Program.

\section{REFERENCES}

1) Neuzil E., Cousse H., Bull. Soc. Pharm. Bordeaux., 132, 121-141 (1993).

2) Neuzil E., Cousse H., Bull. Soc. Pharm. Bordeaux., 132, 142-163 (1993).

3) Sultan C., Terraza A., Devillier C., Carilla E., Briley M., Loire C., Descomps B., J. Steroid Biochem., 20, 515-519 (1984).

4) Briley M., Carilla E., Fauran F., Br. J. Pharmacol., 79, 327-336 (1983)

5) Liotta L. A., Stetler-Stevenson W. G., Semin. Cancer Biol., 1, 99-106 (1990).

6) Fildler I. J., Cancer Res., 50, 6130-6138 (1990).

7) Breu W., Hagenlocher M., Redl K., Titel G., Stadler F., Wagner H., Arzneimittelforschung, 42, 547-551 (1992).

8) Albini A., Iwamoto Y., Kleinman H. K., Martin G. R., Aaronson S. A., Kozlowski J. M., McEwan R. N., Cancer Res., 47, 3239-3245 (1987).

9) Iguchi K., Hamatake M., Ishida R., Usami Y., Adachi T., Yamamoto
H., Koshida K., Uchibayashi T., Hirano K., Eur. J. Biochem., 253, 766-770 (1998).

10) Goodman S. L., Vollmers H. P., Birchmeier W., Cell, 41, 1029-1038 (1985).

11) Van Veldhuizen P. J., Sadasivan R., Cherian R., Wyatt A., Am. J. Med. Sci., 312, 8-11 (1996).

12) Miyake H., Hara I., Yamanaka K., Arakawa S., Kamidono S., Int. J. Oncol., 14, 535-541 (1999).

13) Stephan N. W., Michael J. A., Sephanie T., Christine W., Manfred S., Olaf W., Michael R., Heinz H., Am. J. Pathol., 147, 183-192 (1995).

14) Los M., Zeamari S., Foekens J. A., Gebbink M. F., Voest E. E., Cancer Res., 59, 4440_ 4445 (1999).

15) Tarayre J. P., Delhon A., Lauressergues H., Stenger A., Barbara M., Bru M., Villanova G., Caillol V., Aliaga M., Ann. Pharm. Fr., 41, 559-570 (1983).

16) Délos S., Iehlé C., Martin P. M., Raynaud J. P., J. Steroid Biochem. Mol. Biol., 48, 347-352 (1994).

17) du Toit P. J., van Aswegen C. H., du Plessis D. J., Prostaglandins Lukotr. Essent. Fatty Acids, 51, 121-124 (1994).

18) du Toit P. J., van Aswegen C. H., du Plessis D. J., Prostaglandins Lukotr. Essent. Fatty Acids, 55, 173-177 (1996).

19) al-Roof Higazi A., Aceto J. F., Kniss D., Upson R., Cohen R., Dichek D. A., Cines D. B., Biochemistry, 35, 6884-6890 (1996). 